\title{
THE PROLONGED SURVIVAL OF UPPER RESPIRATORY TRACT AND INTESTINAL PATHOGENS ON SWABS
}

\author{
BY \\ G. N. COOPER \\ From the Public Health Laboratory, School of Bacteriology, University of Melbourne, Australia
}

(RECEIVED FOR PUBLICATION SEPTEMBER 27, 1956)

The provision of a diagnostic bacieriological service is an integral part of the duties of a public health laboratory; while this service operates satisfactorily within the metropolitan area, many medical practitioners in the country areas fail to avail themselves of it. Probably this is mainly due 1o the feeling that the chances of survival of some bacterial pathogens during two or more days' transfort are extremely small. In the hope that this difficulty might be overcome, the survival of a variety of bacterial pathogens has been examined, paricularly in relation to the use of the various means of transporiung clinical specimens recommended by various authors.

The use of cotton-wool swabs for obtaining clinical material for bacterial culture was recommended as early as 1893 by Councilman, while later workers, including Preston (1896) and Hewlett and Nolan (1896), confirmed that such swabs were quite satisfactory. While it was generally agreed that the swabs should be examined as early as possible after collection, very little information relating to the survival of organisms on swabs of this type appeared for some 50 years: in practice there is infinite variation in the conditions to which they are exposed on a particular swab. Rubbo and Benjamin (1951) were probably the first workers to investigate the many factors associated with the problems of delayed culture of all types of bacteria. Previously many workers had been concerned with particular species of bacteria and had evolved methods encouraging the survival of their particular organisms; these methods were, however, not generally applicable and therefore provided no real solution to the problems of transport of all types of bacterial pathogens.

Rubbo and Benjamin advocated the use of a cotton-wool swab impregnated with inspissated serum which effectively prolonged the survival of most pathogens, including the delicate upper respiratory tract bacteria. It was not effective, however, for the extremely sensitive Neisseria gonorrhoeae and $N$. meningitidis. More recently Holmes and Lermit (1955) investigated the problems of enrichment of $\beta$ haemolytic streptococci for survival during transport, basing their investigations on a modification of Pike's (1945) enrichment media; however, such a selective method could not be generally applicable to other bacterial pathogens.

Stuart, Toshach, and Patsula (1954) described a swab kit which was extremely effective in prolonging the survival of $N$. gonorrhoeae in clinical material. They indicated also its possible value for the transport of other clinical specimens: this communication records investigations of the survival of a number of bacterial pathogens and demonstrates that the kit may be used successfully to collect clinical specimens for bacterial culture and diagnosis.

\section{Experimental}

The following procedure was adopted in the examination of survival times of various bacterial species. Unless otherwise stated, swabs were inoculated with $0.05 \mathrm{ml}$. of a saline suspension of organisms, diluted to contain approximately $1 \cdot 10^{6}$ organisms per $\mathrm{ml}$. The suspensions were prepared by washing the 24-hour growth of the organisms off nutrient or serum agar slopes with saline, centrifuging and resuspending the deposited organisms in saline. The opacity of the suspensions was measured against Burroughs Wellcome opacity tubes, and appropriate dilutions of the suspensions were made in saline. The swabs were kept at room temperature and plated on to appropriate media at prescribed intervals. The plates were inspected after 24 or 48 hours' incubation at $37^{\circ} \mathrm{C}$. and the degree of growth was arbitrarily measured in terms of $3 \div, 2 \div$, and $1 \div$, depending on the number of colonies that had developed.

The bacterial species used in these investigations were chosen as representative of most common bacterial pathogens and were divided into three groups, viz., (i) enteric pathogens, (ii) upper respiratory tract pathogens, and (iii) haemophilic organisms.

Most of the cultures used had been isolated recently in the Public Health Laboratory and were usually maintained in the dried state after one or two subcultures 
Comparisons were made between the times of survival of the organisms in the Stuart swab kit (Stuart et al. 1954) and on other types of swabs that are used for the collection of clinical specimens. The examinations were continued for eight weeks and occasionally 12 weeks; cultures were made from individual swabs daily for the first two weeks and subsequently at weekly intervals.

(i) The Enteric Pathogens. - The organisms used were Salmonella typhi, Salm. typhimurium, Shigella flexneri, Sh. sonnei, and Escherichia coli. The time of survival of these organisms on plain cotton-wool, serum-, and charcoal-impregnated swabs was examined. Buffered glycerol saline, which is widely used as a transport medium of faecal material, was included in these investigations. Table I contrasts the survival of the organisms on these swabs with that in the Stuart swab kit.

\section{TABLE I}

PERIODS OF SURVIVAL OF ENTERIC PATHOGENS

\begin{tabular}{|c|c|c|c|c|c|}
\hline \multirow[b]{2}{*}{ Swab or Medium } & \multicolumn{5}{|c|}{ Organism } \\
\hline & $\begin{array}{c}\text { Sh. } \\
\text { sonnei }\end{array}$ & $\begin{array}{c}\text { Sh. } \\
\text { flexneri }\end{array}$ & $\begin{array}{l}\text { Salm. } \\
\text { typhi }\end{array}$ & $\begin{array}{c}\text { Salm. } \\
\text { typhi- } \\
\text { murium }\end{array}$ & $\begin{array}{l}\text { Esch. } \\
\text { coli }\end{array}$ \\
\hline 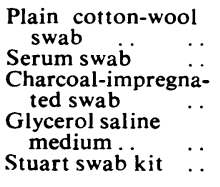 & $\begin{array}{r}1 \text { day } \\
4 \text { days } \\
7, " \\
3, ",\end{array}$ & $\begin{array}{r}1 \text { day } \\
7 \text { days } \\
7, \\
4, \\
>56, "\end{array}$ & $\begin{array}{c}1 \text { day } \\
\text { 10days } \\
14, \\
5, ", \\
>56,\end{array}$ & $\begin{array}{c}1 \text { day } \\
\text { 10days } \\
14, " \\
7, ", \\
>56,\end{array}$ & $\begin{array}{r}1 \text { day } \\
14 \text { days } \\
14,, \\
2, " \\
>56 ”,\end{array}$ \\
\hline
\end{tabular}

Rubbo and Benjamin (1951) showed that the Gram-negative enteric bacilli are relatively resistant, and these results fully confirm their findings; the organisms, while dying out fairly rapidly on plain cotton-wool swabs, survive for periods of one to two weeks on the serum-coated swabs. Moreover, after eight weeks in the Stuart swab kit there was no apparent falling-off in the number of viable organisms recovered on the plates. One interesting feature of these results is the failure of the glycerol saline medium to maintain viability for more than four to five days; even after three days only very few organisms were viable, for only between one and 10 colonies developed on the plates. While this is desirable for the eradication of Esch. coli, it would seem that the toxicity of this medium prevents its recommendation as a transport medium if there is to be a delay of two or more days before specimens reach the laboratory.

A second type of experiment was undertaken in which $5 \times 10^{8}$ organisms were added to approximately $5 \mathrm{~g}$. of autoclaved faecal material. Swabs were then dipped into this material, stored at room temperature and cultured daily for two weeks and subsequently at weekly intervals up to the eighth
TABLE II

SURVIVAL OF ENTERIC ORGANISMS IN AUTOCLAVED FAECES

\begin{tabular}{|c|c|c|c|c|}
\hline \multirow{2}{*}{\multicolumn{2}{|c|}{ Swab or Medium }} & \multicolumn{3}{|c|}{ Organism } \\
\hline & & Sh. sonnei & Salm.typhi & E. coli \\
\hline $\begin{array}{l}\text { Plain cotton-wool swab } \\
\text { Serum swab .. } \\
\text { Charcoal-impregnated swab } \\
\text { Glycerol saline medium } \\
\text { Stuart swab kit .. .. }\end{array}$ & $\begin{array}{l}\cdots \\
\cdots \\
\cdots \\
\cdots\end{array}$ & $\begin{array}{r}2 \text { days } \\
4 \quad, \\
6 \% \\
3 \\
>56 ",\end{array}$ & \begin{tabular}{r|}
2 days \\
10 , \\
10 ,. \\
$4 \quad,$, \\
$>56 \quad$,
\end{tabular} & 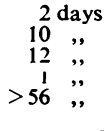 \\
\hline
\end{tabular}

week. In addition, approximately $2 \mathrm{~g}$. of the treated faeces was deposited in the buffered glycerol saline medium and subcultures were taken as before. Table II records the results using Salm. typhi, Sh. sonnei, and Esch. coli. The results show that, in general, the presence of the faecal material does not affect the survival times of the organisms; there is a drop in the period of survival of the organisms on the charcoal-impregnated swabs, but the reason for this is obscure. There has been no associated decrease in survival in the Stuart swab kit.

Survival in Clinical Material.-Faecal specimens were obtained from a number of children in a large institution who were suffering from dysentery caused by $S h$. sonnei. These patients were known to be excreting this organism. Twelve Stuart swabs and six serum swabs were taken from each faecal sample and approximately $5 \mathrm{~g}$. of the sample was deposited in $10 \mathrm{ml}$. of buffered glycerol saline. Cultures from

TABLE III

SURVIVAL OF SH. SONNEI IN CLINICAL MATERIAL

\begin{tabular}{|c|c|c|c|c|c|c|c|c|c|c|c|c|}
\hline \multirow{2}{*}{ Patient } & \multirow{2}{*}{$\begin{array}{c}\text { Faeces } \\
\text { Stored } \\
\text { on }\end{array}$} & \multicolumn{11}{|c|}{$\begin{array}{c}\text { Grganism Isolated } \\
\text { (Days of Examination) }\end{array}$} \\
\hline & & 1 & 2 & 4 & 7 & 14 & 21 & 28 & 42 & 56 & 70 & 84 \\
\hline K. J. (1) & $\begin{array}{l}\text { S.S. } \\
\text { G.S. } \\
\text { S.S.K. }\end{array}$ & $\begin{array}{l}+ \\
+ \\
+\end{array}$ & $\begin{array}{l}+ \\
+ \\
+\end{array}$ & $\begin{array}{l}+ \\
+ \\
+\end{array}$ & $\begin{array}{l}\overline{-} \\
\bar{t}\end{array}$ & $\begin{array}{l}- \\
+ \\
+\end{array}$ & $\overline{-}$ & $\overline{-}$ & $\begin{array}{l}- \\
- \\
-\end{array}$ & $\begin{array}{l}- \\
- \\
-\end{array}$ & $\begin{array}{l}- \\
- \\
+\end{array}$ & $\overline{-}$ \\
\hline K. J. (2) & $\begin{array}{l}\text { S.S. } \\
\text { G.S. } \\
\text { S.S.K. }\end{array}$ & $\begin{array}{l}+ \\
+ \\
+\end{array}$ & $\begin{array}{l}+ \\
+ \\
+\end{array}$ & $\begin{array}{l}+ \\
+ \\
+\end{array}$ & $\overline{-}$ & $\begin{array}{l}\overline{-} \\
\overline{+} \\
\end{array}$ & $\bar{z}$ & $\begin{array}{l}- \\
\\
\end{array}$ & $\begin{array}{l}- \\
- \\
+\end{array}$ & $\begin{array}{l}- \\
- \\
+\end{array}$ & $\begin{array}{l}- \\
- \\
+\end{array}$ & $\overline{-}$ \\
\hline N.W. (1) & $\begin{array}{l}\text { S.S. } \\
\text { G.S. } \\
\text { S.S.K. }\end{array}$ & $\begin{array}{l}+ \\
+ \\
+ \\
\end{array}$ & $\begin{array}{l}+ \\
+ \\
+\end{array}$ & $\frac{ \pm}{+}$ & $\begin{array}{l}\overline{-} \\
\bar{t}\end{array}$ & $\begin{array}{l} \pm \\
\pm \\
\end{array}$ & $\begin{array}{l}- \\
+ \\
\end{array}$ & $\begin{array}{l}- \\
\overline{-} \\
\end{array}$ & $\begin{array}{l}\overline{-} \\
\overline{+} \\
\end{array}$ & $\begin{array}{l}- \\
+\end{array}$ & $\begin{array}{l}- \\
\dot{+} \\
\end{array}$ & $\begin{array}{l}- \\
+\end{array}$ \\
\hline N.W. (2) & $\begin{array}{l}\text { S.S. } \\
\text { G.S. } \\
\text { S.S.K. }\end{array}$ & $\begin{array}{l}+ \\
+ \\
+\end{array}$ & $\begin{array}{l}+ \\
+ \\
+ \\
+\end{array}$ & $\begin{array}{l}t \\
+\end{array}$ & $\begin{array}{l}\overline{-} \\
\overline{+}\end{array}$ & $\begin{array}{l}- \\
\overline{+} \\
+\end{array}$ & $\begin{array}{l}- \\
+ \\
\end{array}$ & $\begin{array}{l}- \\
- \\
+\end{array}$ & $\begin{array}{l}\overline{-} \\
+\end{array}$ & $\begin{array}{l}- \\
- \\
+\end{array}$ & $\begin{array}{l}\bar{z} \\
+ \\
+\end{array}$ & $\overline{\bar{z}}$ \\
\hline N. P. & $\begin{array}{l}\text { S.S. } \\
\text { G.S. } \\
\text { S.S.K. }\end{array}$ & $\begin{array}{l}+ \\
\pm \\
+\end{array}$ & $\begin{array}{l}+ \\
+ \\
+\end{array}$ & $\begin{array}{l}\bar{t} \\
+ \\
+\end{array}$ & $\begin{array}{l}\overline{-} \\
\overline{+} \\
+\end{array}$ & $\begin{array}{l}\overline{-} \\
+ \\
+\end{array}$ & $\overline{-}$ & $\begin{array}{l}\bar{z} \\
\overline{+}\end{array}$ & $\begin{array}{l}\bar{z} \\
+\end{array}$ & $\begin{array}{l}\bar{z} \\
\bar{z} \\
+\end{array}$ & $\begin{array}{l}- \\
- \\
+\end{array}$ & $\overline{-}$ \\
\hline B. E. & $\begin{array}{l}\text { S.S. } \\
\text { G.S. } \\
\text { S.S.K. }\end{array}$ & $\begin{array}{l}+ \\
+ \\
+ \\
\end{array}$ & $\begin{array}{l}+ \\
+ \\
+\end{array}$ & $\begin{array}{l}+ \\
+ \\
+ \\
\end{array}$ & $\begin{array}{l}\bar{z} \\
\pm \\
+\end{array}$ & $\begin{array}{l}- \\
\pm \\
\end{array}$ & $\begin{array}{l} \pm \\
+ \\
\end{array}$ & $\bar{z}$ & $\begin{array}{l}\overline{-} \\
+ \\
+\end{array}$ & $\begin{array}{l}\bar{z} \\
+\end{array}$ & $\overline{-}$ & $\overline{\bar{t}}$ \\
\hline J. J. & $\begin{array}{l}\text { S.S. } \\
\text { G.S. } \\
\text { S.S.K. }\end{array}$ & $\begin{array}{l}+ \\
+ \\
+ \\
+\end{array}$ & $\begin{array}{l}+ \\
+ \\
+\end{array}$ & $\bar{t}$ & $\begin{array}{l}\overline{-} \\
\overline{+}\end{array}$ & $\overline{-}$ & $\overline{\overline{-}}$ & $\begin{array}{l}\overline{-} \\
\overline{-}\end{array}$ & $\begin{array}{l}- \\
\overline{-} \\
+\end{array}$ & $\begin{array}{l}\overline{-} \\
\bar{t}\end{array}$ & $\begin{array}{l}- \\
- \\
+\end{array}$ & $\bar{z}$ \\
\hline
\end{tabular}

S.S. = serum swab. G.S. = buffered glycerol saline. S.S.K. = Stuart swab kit. $+=S h$. sonne $i$ isolated. $-=S h$. sonne $i$ not isolated. 
the swabs and subcultures from the glycerol saline were made at the times shown in Table III. The results clearly indicate the ability of the Stuart swab kit to maintain the viability of this pathogen for at least 10 to 12 weeks. It was not possible, of course, to measure the absolute survival rate of the organism owing to the presence of other faecal organisms which developed on the inoculated plates. However, there was no apparent drop in the ratio of pathogens, for the swabs cultured after 10 and 12 weeks yieided as many colonies as those cultured in the first four days.

Similar experiments were carried out using faeces obtained from patients who were excreting Salm. typhimurium; the results generally paralleled those obtained with Sh. sonnei in that it was always possible to isolate the pathogen from Stuart swabs that had been kept at room temperature for periods ranging from 10 to 12 weeks.

(ii) Upper Respiratory Tract Pathogens.-The organisms examined in this group were Streptococcus pyogenes, Strep. viridans, Corynebacteriumdiphtheriae, and Staphylococcus pyogenes (var. aureus). Table IV shows the results of a typical experiment in which the periods of survival of these organisms were examined on plain cotton-wool swabs, serumcoated swabs, charcoal-impregnated swabs, and in the Stuart swab kit.

TABLE IV

SURVIVAL PERIODS OF UPPER RESPIRATORY TRACT PATHOGENS

\begin{tabular}{|c|c|c|c|c|}
\hline \multirow[b]{2}{*}{ Swab } & \multicolumn{4}{|c|}{ Organism } \\
\hline & $\begin{array}{c}\text { Strep. } \\
\text { viridans }\end{array}$ & $\begin{array}{c}\text { C. diph- } \\
\text { theriae }\end{array}$ & $\begin{array}{c}\text { Strep. } \\
\text { pyogenes }\end{array}$ & $\begin{array}{c}\text { Staph. } \\
\text { pyogenes }\end{array}$ \\
\hline $\begin{array}{l}\text { Plain cotton wool } \\
\text { Serum } \\
\text { Charcoal-impregnated } \\
\text { Stuart kit }\end{array}$ & $\begin{aligned} 4 & \text { hrs. } \\
2 & \text { days } \\
3 & . \\
42 & \cdots\end{aligned}$ & $\begin{array}{r}4 \text { hrs. } \\
3 \text { days } \\
4 \text {,, } \\
>56,\end{array}$ & $\begin{array}{l}4 \text { hrs. } \\
2 \text { days } \\
3 \text {,, } \\
56,,\end{array}$ & $\begin{aligned} 1 \text { day } \\
10 \text { days } \\
10 \quad, \\
>56,\end{aligned}$ \\
\hline
\end{tabular}

Although the period of survival of the streptococci on serum swabs has been recorded as two days, the number of organisms that were viable at this stage was very small; in most experiments only five to 10 colonies developed on the plates after two days on this type of swab, while this small number of colonies were recovered from the Stuart swabs only after 42 days at room temperature.

A similar experiment was carried out in which the survival of $C$. diphtheriae and Strep. pyogenes was compared using serum broth and saline suspensions of the organisms. In this experiment suspensions containing $5 \times 10^{6}$ organisms per $\mathrm{ml}$. were used. In Table $\mathrm{V}$ are recorded the results, and it indicates that the serum broth confers some protection to C. diphtheriae while having no significant effect upon
TABLE V

SURVIVAL OF STREP. PYOGENES AND C. DIPHTHERIAE USING SALINE AND SERUM BROTH SUSPENSIONS

\begin{tabular}{|c|c|c|c|c|c|}
\hline \multirow[b]{2}{*}{ Organism } & \multirow{2}{*}{$\underset{\text { in }}{\text { Suspended }}$} & \multicolumn{4}{|c|}{ Period of Survival on } \\
\hline & & $\begin{array}{l}\text { Plain } \\
\text { Swab }\end{array}$ & $\begin{array}{l}\text { Serum } \\
\text { Swab }\end{array}$ & $\begin{array}{l}\text { Charcoal } \\
\text { Swab }\end{array}$ & $\begin{array}{l}\text { Stuart } \\
\text { Swab }\end{array}$ \\
\hline C. $d$ & $\begin{array}{l}\text { Serum broth } \\
\text { Saline }\end{array}$ & $\begin{array}{l}1 \text { day } \\
1,, .\end{array}$ & $\begin{array}{l}4 \text { days } \\
3 \text {, }\end{array}$ & $\begin{array}{c}21 \text { days } \\
8,,\end{array}$ & $\begin{array}{l}>56 \text { days } \\
>56 \quad, .\end{array}$ \\
\hline 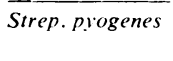 & $\begin{array}{l}\text { Serum broth } \\
\text { Saline }\end{array}$ & $\begin{aligned} & 1 \text { day } \\
< & 4 \text { hrs. }\end{aligned}$ & $\begin{array}{l}3 \text { days } \\
3 \text {, }\end{array}$ & $\begin{array}{l}5 \text { days } \\
5, y\end{array}$ & $\begin{array}{l}>56 \text { days } \\
>56 \quad \text {, }\end{array}$ \\
\hline
\end{tabular}

the haemolytic streptococci. Whether this may be explained purely on a basis of the absorptive powers of the charcoal and serum together is open to doubt, and so far no light has been thrown upon this particular problem. Undoubtedly the factors affecting the viability of the two organisms are not identical. It is noteworthy that the charcoalimpregnated swab is rather better than the serumcoated swab for the streptococci; this may be explained, in part at least, by the fact that these swabs tend to retain their moisture for a longer period than oiher swabs: rapid loss of moisture is undoubtedly deleterious to these organisms, and it may be that this is the main factor governing their survival.

\section{TABLE VI}

SURVIVAL OF $C$. DIPHTHERIAE AND $\beta$ HAEMOLYTIC STREPTOCOCCI IN CLINICAL MATERIAL

\begin{tabular}{|c|c|c|c|c|c|c|}
\hline \multirow{2}{*}{$\begin{array}{l}\text { Patient's: } \\
\text { No. }\end{array}$} & \multirow{2}{*}{\multicolumn{2}{|c|}{$\begin{array}{l}\text { Immediate } \\
\text { Culture }\end{array}$}} & \multicolumn{4}{|c|}{ Growth Obtained from Stuart Swab after } \\
\hline & & & $\begin{array}{l}0-2 \\
\text { Weeks }\end{array}$ & $\begin{array}{c}2-4 \\
\text { Weeks }\end{array}$ & $\begin{array}{c}\text { 4-6 } \\
\text { Weeks }\end{array}$ & $\begin{array}{l}\text { 6-12 } \\
\text { Weeks }\end{array}$ \\
\hline $\begin{array}{l}\text { P. } 4 \ldots \\
\text { P } 5 \ldots \\
\text { P. } 8 \ldots \\
\text { P. } 11 \ldots \\
\text { P. } 21 \ldots \\
\text { P. } 22 \ldots\end{array}$ & $\begin{array}{l}\text { D } \\
\text { HS } \\
\text { D } \\
\text { HS } \\
\text { D } \\
\text { HS } \\
\text { D } \\
\text { HS } \\
\text { D } \\
\text { HS } \\
\text { D } \\
\text { HS }\end{array}$ & $\begin{array}{l}- \\
=- \\
E \\
=- \\
=- \\
=- \\
=-+\end{array}$ & $\begin{array}{l}\ldots+ \\
+\cdots \\
+\end{array}$ & 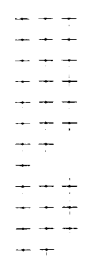 & 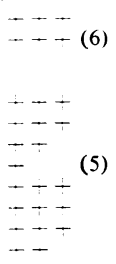 & 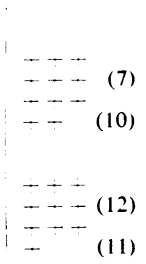 \\
\hline $\begin{array}{l}\text { P. } 9 \ldots \\
\text { P. } 10 \ldots \\
\text { P. } 24 \ldots \\
\text { P. } 25 \ldots\end{array}$ & $\begin{array}{l}\mathrm{D} \\
\mathrm{D} \\
\mathrm{D} \\
\mathrm{D}\end{array}$ & $\begin{array}{l} \pm+ \\
-+ \\
-\end{array}$ & $I I I$ & $\begin{array}{l}\ldots+ \\
\ldots+ \\
+\ldots+\end{array}$ & ++ & $\begin{array}{l}+(11) \\
=-\quad(12) \\
\bar{Y} \quad(10) \\
+\quad(12)\end{array}$ \\
\hline $\begin{array}{l}\text { P. } 2 \ldots \\
\text { P. } 3 \ldots \\
\text { P. } 6 \ldots \\
\text { P. } 7 \ldots \\
\text { P. } 12 \ldots \\
\text { P. } 13 \ldots \\
\text { P. } 14 \ldots \\
\text { P. } 15 \ldots \\
\text { P. } 17 \ldots \\
\text { P. } 18 \ldots \\
\text { P. } 19 \ldots\end{array}$ & $\begin{array}{l}\text { HS } \\
\text { HS } \\
\text { HS } \\
\text { HS } \\
\text { HS } \\
\text { HS } \\
\text { HS } \\
\text { HS } \\
\text { HS } \\
\text { HS } \\
\text { HS }\end{array}$ & 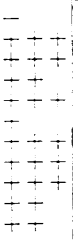 & $\begin{array}{l}+T+ \\
+T+ \\
T+T \\
-F \\
T+ \\
+T+ \\
T+T\end{array}$ & $\begin{array}{l}++ \\
-+ \\
-++ \\
-++ \\
-+\div \\
++ \\
-+\end{array}$ & $\begin{array}{l}-+(6) \\
-\quad(5) \\
+++(6) \\
+-(6) \\
+\square+ \\
+\square \\
+-\end{array}$ & $\begin{array}{l}+-\quad(8) \\
+-T \quad(9) \\
++-(10) \\
++-(11) \\
++\quad(12) \\
+-\quad(11)\end{array}$ \\
\hline $\begin{array}{l}\text { P. } 16 . \\
\text { P. } 20 .\end{array}$ & $\begin{array}{l}\text { D } \\
\text { D }\end{array}$ & HS - & $=$ & - & $\overline{-}$ & - \\
\hline
\end{tabular}

$\mathrm{D}=C$. diphtheriae. $\mathrm{HS}=\beta$ Haemolyticstreptococci. $+++=>200$ colonies. $\quad+-=50-200$ colonies. $\quad+=20-50$ colonies. Figures in parentheses indicate week of last culture. 
Survival in Clinical Specimens.-Specimens in the form of throat swabs were obtained from Fairfield Infectious Diseases Hospital. The following plan was adopted in these investigations: on admission of patients with symptoms suggestive of diphtheria or streptococcal infections a throat swab was taken for examination by the hospital laboratory. At the same time three Stuart swabs from the patient's throat were taken and forwarded to the Public Health Laboratory where they were kept at room temperature and examined at periods ranging from one to 12 weeks. Thus three examinations could be made from each patient and the results could be compared with those obtained from the swabs which had been cultured at the hospital within a few hours of collection. The amount of growth of the pathogens was recorded according to the key described in Table VI, which shows the results of these investigations.

In all, 23 patients were examined, six of whom yielded positive cultures for $C$. diphtheriae and Strep. pyogenes; four patients produced cultures of $C$. diphtheriae alone and 11 were found to have Strep. pyogenes. With two patients no pathogens were isolated either from the immediate culture or from Stuart swab kits. There can be no doubt that the Stuart swabs have a remarkable ability to maintain the viability of these rather delicate pathogens. In most cases there was no indication of a drop in the number of viable organisms on the swabs over a period of eight weeks, and only after periods of 10 to 12 weeks does there seem to be some decrease in numbers.

(iii) Haemophilic Organisms.-A series of experiments similar to those described for the upper respiratory tract pathogens was carried out using suspensions of Haemophilus influenzae type b, $H$. pertussis, and H. aegyptii (Koch-Weeks bacillus).

TABLE VII

SURVIVAL PERIODS OF PATHOGENIC HAEMOPHILUS SPP.

\begin{tabular}{|c|c|c|c|c|c|}
\hline \multirow{2}{*}{\multicolumn{2}{|c|}{ Organism }} & \multicolumn{4}{|c|}{ Period of Survival on } \\
\hline & & $\begin{array}{c}\text { Plain Cotton- } \\
\text { wool Swab }\end{array}$ & $\begin{array}{l}\text { Serum } \\
\text { Swab }\end{array}$ & $\begin{array}{c}\text { Charcoal } \\
\text { Swab }\end{array}$ & $\begin{array}{c}\text { Stuart } \\
\text { Swab Kit }\end{array}$ \\
\hline $\begin{array}{l}\text { H. influenzae } \\
\text { H. aegyptii } \\
\text { H. pertussis }\end{array}$ & $\begin{array}{l}\cdots \\
\cdots \\
\cdots\end{array}$ & $\begin{array}{l}<4 \text { hours } \\
<4, \\
<4,\end{array}$ & $\begin{array}{l}1 \text { day } \\
1 \text {,", } \\
1 \text {," }\end{array}$ & $\begin{array}{l}2 \text { days } \\
4 \text {,", } \\
2 \text { ", }\end{array}$ & $\begin{array}{l}28 \text { days } \\
35 \quad, " \\
28, "\end{array}$ \\
\hline
\end{tabular}

Table VII records the results of a typical experiment. The results indicate that these organisms are more susceptible to death on swabs than are those previously studied, and that all are very similar in the periods that they survive on various types of swabs. Once again the Stuart swab kit has a striking advantage over other types of swabs. It was not possible to undertake any investigations of clinical material containing these organisms, but on general principles it would seem reasonable to expect these organisms to remain viable for a period of at least two or three weeks.

\section{Discussion}

The important feature of these results is the remarkable ability of the Stuart swab kit in maintaining the viability of the pathogenic organisms used in this study. These organisms are probably representative of the pathogenic bacteria encountered in a public health laboratory. On these results it is possible to formulate the expected period of survival of the various types of pathogens in clinical material thus:

\begin{tabular}{|c|c|c|c|c|}
\hline \multicolumn{4}{|l|}{ Organism } & Expected Survival \\
\hline $\begin{array}{l}\text { Enteric pathogens } \\
\text { C. diphtheriae .. } \\
\beta \text {. Haemoly.ic streptococci } \\
\text { Staph. pyogenes } \quad . . \\
\text { Haemophilus spp. } \quad . \\
\text { Pathogenic Neisseria }\end{array}$ & $\begin{array}{l}\cdots \\
\cdots \\
\cdots \\
\cdots \\
\cdots\end{array}$ & $\begin{array}{l}\cdots \\
\cdots \\
\cdots \\
\cdots \\
\cdots\end{array}$ & $\begin{array}{l}\cdots \\
\cdots \\
\cdots \\
\cdots \\
\cdots\end{array}$ & $\begin{array}{c}12 \text { weeks } \\
8 \quad,, \\
6-8 \quad, \\
12,, \\
3 \\
4-7 \text { days (see } \\
\text { Stuart et } \text { al., 1954) }\end{array}$ \\
\hline
\end{tabular}

These expected survival times contrast greatly with the few days of survival on other types of swabs and in other forms of transport that may be used for specimens. It is felt, therefore, that the Siuart swab kit will provide medical practitioners in country areas with a greater opportunity for cultural diagnosis, as problems of delay in transport and delivery are virtually overcome.

Moreover, this kit lends itself admirably to many projects which previously had been difficult to undertake. For instance, large-scale field surveys could be undertaken in areas which possess no laboratory facilities, for it is possible to keep the clinical material for a matter of weeks and be assured of recovering any pathogenic organisms when the specimens are returned to a central laboratory. One other possibility is that this swab kit might be adapted for maintaining viruses, at least for short periods.

Stuart (1946) suggested that the mechanisms encouraging the survival of organisms in the swab kit were primarily the prevention of drying and oxidation. The organisms are completely enclosed in a moist, semi-liquid medium which is kept anaerobic by the thioglycollic acid. In addition, the absence of nutrients in the medium prevents any organism from growing; thus there is no possibility of commensal organisms outgrowing the pathogen, an objection applicable to many other types of 
transport media. This has an added benefit in that it offers a better opportunity to study the aetiological relationship of pathogens and non-pathogens in any site of the body, for we are no longer confronted with the problems of differences in viability of different organisms, nor with the tendency for some organisms to outgrow others during the period between collection and culture of the specimen.

The charcoal-impregnated swab was originally used by Stuart to prevent toxic fatty acids, present in some batches of agar, from killing N. gonorrhoeae; from a number of other pieces of evidence we feel that the charcoal may absorb toxic factors which are actually produced by the organisms themselves. Naturally, metabolism does not cease immediately the organisms are collected on the swabs, and it seems likely that their by-products, unless removed in some way, could become inhibitory or lethal. The nature of these substances is obscure and, while it is tempting, along with many other workers, to choose long-chain fatty acids as the most likely type, this is by no means certain. Certainly, attempts to demonstrate a lethal activity, as opposed to bacteriostasis, by fatty acids in very low concentrations have so far failed.

\section{Summary}

The periods of survival of a number of bacterial pathogens on various types of cotton-wool swabs and transport media have been investigated.
These results have been compared with those obtained using the Stuart swab kit. This transport kit has an outstanding ability to prolong the survival of all bacterial pathogens examined.

The use of the swab kit for clinical material containing upper respiratory tract and enteric pathogens is recommended, as it has been possible to recover these organisms after eight to 12 weeks' storage at room temperature.

It is felt that this swab kit should overcome most problems of transport of specimens for bacteriological culture, especially those associated with delays in reaching the laboratory from distant country areas.

The possible mechanisms affecting the survival are discussed and the various uses to which the kit may be put are mentioned.

The author would like to thank Dr. A. A. Ferris and the staff at Fairfield Hospital for the assistance they have given in the collection of swabs from patients, and for the use of their bacteriological reports.

\section{REFERENCES}

Councilman, W. T. (1893). Amer. J. med. Sci., 106, 540.

Hewlett, R. T., and Nolan, H. (1896). Brit. med. J., 1, 266.

Holmes, Margaret C.. and Lermit, Ann (1955). Monthly Bull. Minist. Hith, 14, 97.

Pike, R. M. (1945). Amer. J. H.g., 41, 211.

Preston, W. J. D. (1896). Brii.med.J., 1, 1243.

Rubbo, S. D., and Benjamin, Mary (1951). Ibid., 1, 982.

Stuart, R. D. (1946). Glasg. med. J., 27, 131.

- Toshach, Sheila R., and Patsula, Teresa M. (1954). Canad. J. publ. Hlth, 45, 73 . 